\title{
A Preliminary Study on The Formation of Land Legislation and Cadastre System in Sarawak, Malaysia
}

\author{
Toh Ming Liang, Tan Liat Choon, Tan Wee Vern, Muhamad Uznir bin Ujang, Thoo Ai Chin
}

\begin{abstract}
Recent decades have witnessed a perceptible impact of land policy and cadastre on the urbanisation around the globe. Land legislation and cadastre system are the tools and mechanisms in order to achieve the objectives of land policy in delivering sustainable development. According to the Federal Constitution of Malaysia, article 74 empowers the State Legislative Assemblies to enact laws for the matters under the state list while land matters are one of the subjects under the list. Land matters in Sarawak are governed by Sarawak state government, resulting in different land legislation and cadastre system as compared to Peninsular Malaysia. Therefore, this paper aims to give an overview on the land legislation and cadastre system in Sarawak. The chronological evolutions of land legislation from the past to present are discussed. The cadastre system in Sarawak is also presented. On top of that, this paper attempts to review the literature concerning the subject matter of land legislation and cadastre from various countries, which in turn provides valuable lessons for Sarawak. A total of eight recent publications were chosen for review. Each of the publications is analysed based on the title, subject matter, research question, methodology, results and lessons for Sarawak. Towards the end of this paper, the key lessons from the review are presented.
\end{abstract}

Keywords: Land Legislation, Cadastre, Sarawak, Malaysia, Land and Survey Information System.

\section{INTRODUCTION}

Land policy and cadastre system have a perceptible impact on the urbanisation around the globe. The implementation of appropriate land policy and cadastre system catalysed the process of land development. Undeniable, it is not a stagnant process whereby the land policy and cadastre system might undergo changes over time in order to cater with the current needs from the legal, institutional and technical aspects.

Land means differently to lawyers and laymen; to the former, land is related with rights, responsibility and restriction of a volume of space from the centre of earth to the infinite in the sky [1]. For the latter, land is a space to live and

to enjoy. Land legislation is the law that governs and regulates land development to ensure the sustainability in a country. It is often linked to land administration system (LAS) where whereby LAS acts as a platform to enforce land legislation through systematic recording of land use,

Revised Manuscript Received on April 19, 2019.

Toh Ming Liang, Faculty of Built Environment and Surveying, Universiti Teknologi Malaysia, Skudai, Johor, Malaysia.

Dr. Tan Liat Choon, Faculty of Built Environment and Surveying, Universiti Teknologi Malaysia, Skudai, Johor, Malaysia.

Tan Wee Vern, Faculty of Built Environment and Surveying, Universiti Teknologi Malaysia, Skudai, Johor, Malaysia.

Dr. Muhamad Uznir bin Ujang, Faculty of Built Environment and Surveying, Universiti Teknologi Malaysia, Skudai, Johor, Malaysia.

Dr.Thoo Ai Chin, Azman Hashim International Business School, Universiti Teknologi Malaysia, Skudai, Johor, Malaysia. land tenure and land value [2],[3],[4].

LAS is designed as a mechanism to support land management for implementing sustainable land policies in a country. The needs from the public administration and citizens should be taken into account to fit to the initial purpose of a LAS [5]. However, not all LAS are able to meet the growing demands especially in this era of information. Thus, there are always rooms for improvement for a LAS based on the contemporary needs emerged over time.

On the other hand, the initial purpose of cadastre was designed for fiscal which can be dated back to early nineteenth century in European countries [6]. In order to cater for the growing demands of land development, cadastre has been developed into multipurpose cadastre. This led to the formation of modern cadastre where fiscal cadastres support land taxation and valuation; juridical cadastres deal with legal aspect such as land tenure security; multipurpose cadastres facilitate land management and land use planning which encompass fiscal and juridical cadastre [1].

Similar to LAS, the role of cadastre changes over time. Apart from multipurpose cadastre, numerous theories and works have been developed namely; Cadastre 2014, 3D cadastre, 4D cadastre, Cadastre 2.0 and Cadastre 2034. Cadastre 2014 is a concept developed by Federation Internationale de Geometres (FIG) Commission 7 which consider worldwide social, legal, economic, and technical development in the domain of cadastral systems as a replacement for the traditional cadastral institution [7]. 3D cadastre registers and gives insight into rights and restriction not only on parcel, but also on 3D property units [8]. On top of that, by adding the temporal aspects, Oosterom et al. [9] explores the need for a 4D cadastral system. In Malaysia, the cadastral system does not fully recognise $3 \mathrm{D}$ objects and 3D property registration yet but various works has been established towards 3D cadastre in Malaysia [10];[11];[12].

Driven by technological changes, Cadastre 2.0 emerged as a technology vision for the cadastre which utilised new technologies to improve the existing system [13]. In Malaysia, in line with the FIG's vision of cadastre 2.0, SmartKADASTRE project was initiated to equip the multipurpose cadastre with cadastral-based spatial analysis platform to create a smart multipurpose environment [14]. Cadastre 2034 is the extended vision of cadastre 2014 which purpose is to shape the future cadastre by continuing the

Published By:

Blue Eyes Intelligence Engineering 
International Conference on Recents Advancements in Engineering and Technology (ICRAET-18) |15th and 16th March 2019|Siddhartha Institute of Technology \& Sciences, Telangana, India.

principle developed in Cadastre 2014 [15]. Land policy, land administration system and cadastre are interrelated. A successful cadastre system is the engine of LAS which expedites the process of land registration, increases the security of land tenure, enables systematic planning of land use and facilitates land development in order to achieve the objectives of land policy.

\section{A. Background of Sarawak}

Sarawak, also known as the Land of Hornbill, is the largest state among the 13 states in Malaysia. In fact, Sarawak has the size almost equal to Peninsular Malaysia, covering an area of 124,450 square kilometres with the population of 2.79 million of 6 major ethnic groups [16]. Sarawak is located in northwest region on the island of Borneo.

According to Federal Constitution of Malaysia, land is a state matter. The federal parliament in many circumstances has the power to make laws with respect to land matters for the purpose of ensuring uniformity of law and policy in all the eleven states in Peninsular Malaysia. However, this federal government's power conferred by Article 76 cannot be extended to Sarawak. Hence, land matters in Sarawak are governed by Sarawak state government. Nevertheless, this led to the unique system in Sarawak whereby land, survey, planning and valuation services are integrated under an organisation - Sarawak Land and Survey Department.

\section{B. Institution and management}

Institutions are the main mechanism to transform the legal and the policy framework into action. In other words, the success of a land administration system depends on the functionality of the managing institution. In Sarawak, the institution which responsible for land matters is the Sarawak Land and Survey Department which is under the portfolio of the Minister of Urban Development and Natural Resources.

With the vision to administer and manage land excellently, Sarawak Land and Survey Department is responsible for matters related to land, survey, planning, valuation and enforcement of land legislations under the Sarawak Land Code. Hence, it is a multi-purpose organisation with an integrated system to serve the needs for the people and the state.

\section{Aim and structure of this paper}

The study gives an overview on the land legislation and cadastre system in Sarawak as well as insights from other countries as a lesson for Sarawak. This paper is organised into five sections, as follow. Section 1 introduces the background and objectives of the study. Section 2 provides a chronological evolution of land legislative in Sarawak as well as the current cadastre system in Sarawak. Section 3 discusses the methodology of this paper. Section 4 relates the latest findings on the land legislation and cadastre with Sarawak. Finally, Section 5 concludes the study.

\section{LITERRATURE REVIEW}

\section{A. Land Legislation in Sarawak: A chronological evolution}

For a better grasp on the nature of the legislation, it is essential to take a look back into the historic aspects of land legislation in Sarawak which can be categorised into pre-
Brooke Sarawak, the Brooke Era 1841-1946, and British Crown Colony 1946-1963.

\section{B. Pre-Brooke Sarawak}

Traditionally, the system of land tenure was based on 'adat' (native customary laws) whereby land rights are conferred to the person who cultivates virtual land [17]. A formal definition of native is given by Article 161A clause 6 of Federation Constitution which refers native as the heterogeneous indigenous peoples of Sarawak and Sabah.

Native customary rights (NCR) included the rights to cultivate land, collection of forest products, hunting, burial as well as inheritance. Usually the inheritance of land is being passed down by oral method. Until present, NCR is still recognisable under section 5, 6, 15 and 18 of the Sarawak Land Code (Cap. 81) which is the current land legislation in force.

\section{The Brooke Era (1841-1946)}

From 1841 to 1946, Sarawak was ruled by the Brooke family namely: James Brooke, Charles Vyner Brooke, Bertram Brooke and Anthony Brooke. This era marks the beginning of Sarawak with the identifiable geographical and political entity under the sovereign of Brooke Rajah. Due to the fact that NCR is a major issue in Sarawak, the Brookes did not interfere with it. On the contrary, the Brookes allowed the Dayaks and Malays to govern their own customary land rights.

As the land disputes becoming more common, the need to administrate the land becoming more urging. Hence, on 1842, James Brooke promulgated the Code of Law which regulates the land socially and economically. This led to the formation of Land Regulations in 1863, the first land legislation which stated all unoccupied and waste lands belongs to the government. Under Land regulation 1863 , applicants were eligible for a lease of government land up to 900 years [17].

When more areas were acquired by the Rajah, a new land legislation was much needed at that time. This then led to the next major land legislation namely; Land Order 1920 (Order VIII). Land Order 1920 compromised all the previous land orders with respect to land administration. As a result, land administration in Sarawak was further improved under the governance of the third Brooke Rajah, Charles Vyver Brooke in the early twentieth century [18]. State law was redefined to "all lands which are not leased, granted or lawfully occupied by any person and includes all lands which hereafter may become forfeited or may be surrendered by the lawful owner thereof" [17].

In 1928, English law was formally applied through Order L-4 (Laws of Sarawak Ordinance). The effect of this enactment was two-fold. First, it applied the English law to Sarawak in appropriate circumstances and second, it respected the supreme privileges of the custom law. Three years later, Land Order 1931 (Order L-2) was introduced to further consolidate the land legislation in Sarawak. Order L2 enabled registration of titles and land transaction with a 
clear definition of grants, lease and state land [19].

This was followed by Land Settlement 1933 (Order L-7) which required all lands to be registered for guaranteed boundaries and titles based on accurate cadastral survey. Nasser and Salleh [19] further added that new land register was created for the registration purpose under Land Settlement 1933. Thus, this reflected the principle of Torrens system in Sarawak.

\section{The British Crown Colony (1946-1963)}

Land administration in Sarawak continued to improve and reform after the cession of Sarawak to British Crown in 1946. For instance, Order L-2 and Order L-7 with their amendments were incorporated in the Laws of Sarawak (Revised Edition) 1948. Land Ordinance (Cap. 27) replaced Order L-2 while Land Settlement Ordinance (Cap. 28) replaced Order L-7.
The next significance land legislation was the Land (Classification) Ordinance, No. 19 of 1948 which came into operation on first January 1949. As suggested by the title of the legislation, it classified the land into 5 categories; mixed zoned land, native area land, native communal reserve, reserved land, interior area land and native customary land. Most of the land categories are still in practice today.

Finally, in order to consolidate all existing land legislations which some are overlapping, a new comprehensive land code was drafted by J Caradus; the Land Code (Sarawak Cap. 81). Under the Torrens system of Sarawak Land Code 1958, A person is given the indefeasibility of titles once the interest is registered and document of title is issued. The main purpose of the Sarawak Land Code is to facilitate land administration in Sarawak to deliver sustainability in land development.

Table. 1 Land Legislation in Sarawak

\begin{tabular}{lll}
\hline \multicolumn{1}{c}{ Event and date } & \multicolumn{1}{c}{ Main Land Legislation } & \multicolumn{1}{c}{ Brief Description } \\
\hline $\begin{array}{l}\text { Pre-Brooke Sarawak } \\
\text { (Before 1841) }\end{array}$ & Native customary law & $\begin{array}{l}\text { The clearing and cultivation of virgin land } \\
\text { confers permanent rights on the original clearer }\end{array}$ \\
\hline $\begin{array}{l}\text { The Brooke Era } \\
(1841-1946)\end{array}$ & Land Regulations of 1863 & $\begin{array}{l}\text { Passed in Supreme Council whereby provision } \\
\text { was made for the alienation of unoccupied and } \\
\text { waste lands }\end{array}$
\end{tabular}

Land Order 1920 (Order No VIII)

Introduced English law. Issued other land regulation such as The Supplementary Order

Laws of Sarawak Ordinance 1928 The formal application English law

(Order L-4)

Land Order 1931 (Order L-2)

Provides Registration of titles and land transactions

Land Settlement 1933 (Order L-7) Guarantee boundaries and titles by creating new Land Register based on accurate Cadastral surveys

The British Crown Land Ordinance (Cap. 27) Incorporated Order L-2 and the amendments

Colony (1946-1963)

Land Settlement Ordinance (Cap. 28) Incorporated Order L-7 and the amendments

Land (Classification) Ordinance No 19 Promulgated a system of land Classification of 1948 which divide land into 5 categories

The Land Code (Sarawak) (Cap. 81) The current main land legislation in force 


\section{E. Sarawak Land Code 1958 (Cap. 81)}

To date, the Sarawak Land Code 1958 (Cap. 81), also known as the Land Code, is the most comprehensive piece of legislation that provides the legal framework for the land development in Sarawak. Since its enactment in 1958, the Land Code has been amended several times to keep abreast with the changing economic and social conditions in order to benefit the people and state. According to section 3 of the Land Code, this Land Code is administered by the Director of Lands and Surveys who is in turn assisted by Deputy Directors, Assistant Directors, Superintendents, Assistant Superintendents, Settlement Officers, Assistant Settlement Officers, Registrars, Assistant Registrars and Surveyors.

The Land Code provides for the Torrens system features of the importance of registration (section 112), the provision for caveats (section 173) and the concept of indefeasibility(section 132). Generally, there are ten (10) parts and two (2) schedule under the provisions of the Land Code which provide the legislative framework for the classification of land, alienation of state land, administration of alienated land, adjudication of native customary rights, cadastral survey, registration of dealings in land and the development of land.

\section{F. Land and Survey Information System (LASIS)}

Cadastre is an engine of land administration system by the integration of cadastral data and legal data through an information system to support the functions of land tenure, land value, land use and land development [5]. LASIS is an integrated system implemented by Sarawak Land and Survey Department since 1984 to facilitate LAS in Sarawak.

LASIS is the integration of information systems such as the core system, Cadastral Mapping System (CMS), Valuation Information system (VIS), Land Administration and Adjudication System (LAAS), Planning Information System (PLIS) and Enforcement Information System (EIS) [20]. Aside from this, there are also system to cater the core business of Sarawak Land and Survey Department namely Survey Computation System (SCS), Aerial Photograph Information System (APIS), Title Registration System (TRS) and Revenue System (RVS) (Fig. 2). LASIS acts as a multipurpose GIS-Database system with shared database among the systems to support land administration, land management and land development in Sarawak.

With the advancement of technology, Sarawak Land and Survey Department has taken a prominent step to launch eLASIS and m-LASIS which are the web and mobile based application. In this boundless world, e-LASIS and m-LASIS enable efficient online services anywhere and anytime. Maps and plans are available through e-Map service, payment of land rent and premium through e-Rent, online submission by e-Lodgement and e-Submission, Searching of document of title through e-Search, land dealings by e-PD and Renewal of Land lease through e-RLL service.

The implementation of LASIS has successfully expedited the delivery process of land titles, land dealings and land registration in Sarawak. LASIS will continue to improve in terms of service delivery, security, reliability and efficiency

Figure 2. Cadastre system in Sarawak - LASIS.

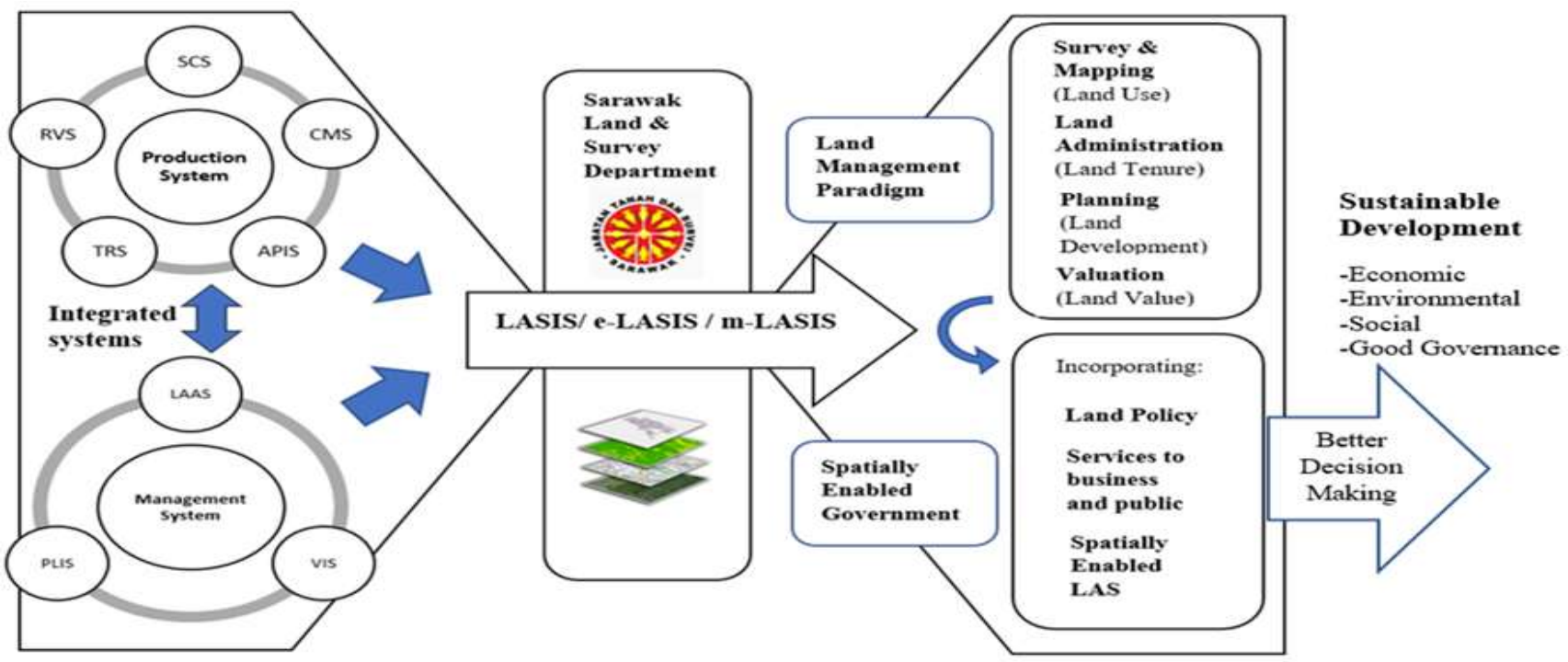

Source: Partially adapted from [5]

\section{METHODOLOGY}

This study employs the commonly used research method namely the documentary research method. Documentary method refers to the analysis of documents or publications that related with the discipline one wishes to study [21]. There are two phases in this study. In the first phase, documents such as books, reports and journal papers are reviewed. The chosen documents are closely related to land legislation and cadastre system in Sarawak. The analysis of these documents formed the literature review of this study.

In the second phase, eight recent publications were chosen with the subject matter of land administration, land legislation and cadastre. These publications are from various 
countries namely: Benin, Ethiopia, Ghana, Netherlands, Poland, Turkey, and Malaysia. Each of the publications are analysed based on the title, subject matter, research question, methodology, results and most importantly, lessons for Sarawak.

\section{RESULT AND FINDINGS}

There are many developed countries with matured land legislation and cadastre system which can provide valuable lessons to Sarawak, Malaysia. It is always a smart and effective way to learn from other's experience. This section summarised the findings from previous literatures. The literatures are selected based on the related subject namely; land administration, land legislation and cadastre system which in turn provide lesson for Sarawak (Table 2).

\section{A. Land administration}

Abubakari et al. [22] explored the implementation gap caused by ambiguity and contradictions between laws and implementation practices which affects the land registration in Ghana. Based on the discussion, the nature of the implementation gaps could be explained in three domains. Firstly, trade-off between legal simplification and complexity in the reality. A legislation can be simple to understand but the subsequent implementation will encounter hindrances caused by the complexity of the reality. Secondly, adaptiveness of the implementers. The unique disposition of implementers could affect how the legislation is implemented. Thirdly, administrative capacity such as human resources and material resources.

On the other hand, Sarawak is also facing such implementation gap in a similar way. Thus, the factors that influence the implementation gap analysed by this study can provide insight for Sarawak to tackle such gaps. For instance, ambiguity of the law caused by unclarity in the law itself. Besides, negative attitude of the implementers which contradict to the objectives of the law and human resources such as insufficient administrative staffs with adequate knowledge in this field further widen the gaps.

One of the main functions of land administration in Sarawak is to ensure the indefeasibility of land tenure with respect to the registration and adjudication of customary rights [23]. However, security breaches of land tenure are still rampant in Malaysia. In the paper "Land Registration of Titles at Stake: West and East Malaysia Compared", Nuraisyah et al. [24] provided solutions to address the weaknesses of the registration system in Malaysia. In the paper, the emphasis is placed on two domains. Firstly, factor that contributes to the fraud cases in title registration. Secondly, how to overcome the problems.

Nuraisyah et al. [24] stated some factors that lead to fraud cases in Malaysia. Among them are the high-priced property that motivates the fraudsters, land abandonment, weaknesses in the registration system which open space to the falsification of documents and inherent weaknesses of the Malaysia land legislation. Based on the statistics of the fraud cases in Malaysia, Sabah recorded the highest number of cases. The possible explanation is that Sabah Land Ordinance (Cap. 68) is not modelled on the Torrens System of land registration as the provision that conferring indefeasibility of title is missing. Therefore, it is a fact that land legislations which modelled on the principle of Torrens System such as National Land Code 1965 (Act 56) and Sarawak Land Code 1958 (Cap. 81) could enhance the security of land tenure.

In Peninsular Malaysia, the electronic system for land management is called the $e$-Tanah system while in Sarawak, Land and Survey Information System (LASIS) is initiated to facilitate land management. However, electronic land registration system had been proven to be vulnerable to fraud and other types of cyber-crimes. Improvement has to be done to strengthen the land registration security. Among them are the regularly conduction of audit trails to detect abnormalities in the systems, conduction of specific training to improve effectiveness of the administrators and the adaptive changes in the organisational structure, policy and management system with respect to the current need in land management [24].

Klimach et al. [25] highlighted the principles of good governance in Polish LAS, namely; openness, participation, accountability, effectiveness and coherence. Participation, the role of citizen in restructuring land policy, is essential especially for country with multi-races. The LAS in Poland is known as Integrated Real Estate Information System (IREIS). Similar to Sarawak, Land and Survey Information System (LASIS) is also an integrated cadastre system with shared database among the departments. Klimach et al. [25] further described the benefits of an integrated system, for instance, smoothen the process of error detection, strengthen the reliability of data and facilitate public services. Hence, in order to ensure LASIS in supporting good governance, analysis could be done in accordance to the principles of good governance in Polish LAS.

Enemark et al. [26] highlighted the strategies to implement Fit-For-Purpose (FFP) land administration especially in developing countries. In conjunction with the global agenda, Sustainable development Goal [27]; FFP land administration provide pragmatic approach to deliver sustainability in land development. In order to realise FFP land administration, there are seven principle to be fulfilled, namely; flexible, inclusive, participatory, affordable, reliable, attainable and upgradable [28].

Based on the paper "Implementing Fit-For-Purpose land administration at Country Level" by Enemark et al., one of the guiding principles for building FFP land administration system is a detailed analysis of a country context. The country context in terms of existing spatial, legal and institutional framework will shape the way that FFP land administration can be implemented. The analysis will also determine the basic objectives of a country's existing land administration to ensure that the solution for implementing FFP land administration is in line with objectives and is feasible throughout the county.

In Sarawak, the implementation of FFP land administration system could be a promising way to transform the current land administration into a system that handles that current needs from political, policy, organisation, technical and societal aspects. Moreover, the 
systems are designed to manage the land effectively without the use of high-end technology which are costly and impractical. Undoubtedly, FFP principles are suitable for developing countries and in line with the six principles to modernise Sarawak land administration highlighted by Osman \& Kueh c.

\section{B. Land Legislation}

Ekpodessi \& Nakamura [29] evaluated the effectiveness of the current land legislation in Benin Republic (Land Law 2013-01) in terms of the implication and impact of the main modes of land access. Ineffectiveness of land management is rampant in Benin Republic, causing insecurity in land tenure. Hence, Land Law 2013-01 was implemented as a framework to tackle to issue regarding land. However, since the implementation of the law, land use in Benin still remains as a huge challenge for Benin government.

Based on the interpretation, one of the key issues emanated from the land access modes is the legal dualism created by the coexistence of customary and modern rights. Contradiction between land policies and practices caused inability of traditional land tenure to co-exist alongside with the formal land laws [18]. In Sarawak, there are also native customary rights (Section 5 of Sarawak Land Code, 1958) and modern land rights, also known as the registration system (Section 112 to 136, Sarawak Land Code, 1958). However, there isn't any clear remedy provided, which is beyond the scope of this paper. Nevertheless, the lessons from Benin Republic can still acts as a reminder for Sarawak as a need to deliver a clear land policy through effective land legislation.

Holtslag-Broekhof [30] explored the reasons to implement urban land readjustment (URL) in Netherlands which lead to the necessity for a new legislation on ULR. Land readjustment is an instrument used to facilitate urban land development in which the owners swap land positions and share the development costs and gains [31]. According to Holtslag-Broekhof [30], ULR is a potential method to facilitate urban developments with the advantages namely; effectiveness, efficiency, openness and fairness. She also identified the reasons to use ULR as an alternative way of land management strategies in Netherlands. The main rationale is that ULR solves issues related to financial and property structure. Based on the data gathered through literature reviews, case studies and feedback from experts, she concluded that a comprehensive ULR legislation is indeed necessary to guide and facilitate the land instrument.

In Sarawak, the main purpose of land resettlement is to eradicate poverty especially for indigenous peoples with native customary rights. Too often, the joint venture concept did not promise satisfactory results as most of the issues regarding the low financial returns as well as the long period of 60 years contract. Landowners faced difficulties to regain their land resources as they have to wait for the 60-year terms to expire first [32]. Therefore, a new policy for land resettlement could be the long-term solution for the issues. Experiences from other countries could be a good input for the design of a new land policy for land readjustment in Sarawak.

\section{Cadastre}

Polat et al. [15] determined a framework to analyse the integration of land and cadastre system in Turkey with the principles of the Cadastre 2034 vision based on Strengths, Weaknesses, Opportunities, and Threats (SWOT) and Analytic Hierarchy Process (AHP) analysis. In Turkey, the General Directorate of Land Registry and Cadastre (GDLRC) is the main institution which responsible for activities related to land administration and cadastre. Similar to Sarawak Land and Survey Department, the organisation operates under one roof, which facilitates the execution of land registry and other cadastre activities.

Cadastre 2014 is a vision and an approach to modernise traditional cadastral system [7] while Cadastre 2034 continues the reform process as developed in Cadastre 2014 [15]. In order to ensure the development of land administration and cadastre system is in line with the principle of Cadastre 2034, analysis can be done in terms of legal, institutional and technical aspects. As compared to other developed countries, Sarawak is still far cry from achieving the visions of Cadastre 2034. However, the SWOT-AHP method of analysis can be used to benchmark the current status of Sarawak land and cadastre system, which in turn provides opportunities and recommendations for further improvement.

A good land governance required a sustainable LAS and cadastre is indeed the engine of the entire LAS [33].The cadastre system has to be examined to ensure its functionality. Alemie et al. [34] examined the impacts of evolving urban cadastre on urban land governance across three governing regimes in Ethiopia using cadastral 'toolbox' approach. The toolbox elements consist of political, policy and legal, technical, organizational and societal. Based on the key lessons, driver of cadastre changes from time to time and is it important to accept the changes over time. Most of the countries started from a cadastre with fiscal basis, towards multipurpose cadastre, then towards security aspect in land tenure. Adaption to the current need is one of elements that make a well-developed cadastre. Bottom-up approach is also equally important to top-down approach as input from the citizen level aids in designing a cadastre system.

In Sarawak, the multi-ethnic environment may hinder the process as there are diversity in societal needs. Thus, cadastral 'toolbox' which compromised multiple analytical elements including society, is an appropriate approach to examine cadastre system and land governance in Sarawak. Land governance and management in Sarawak shall be reviewed regularly from time to time to ensure the consistency with the principles of sustainable development [23]. 
Table. 2 A review

\begin{tabular}{|c|c|c|c|c|c|}
\hline Title (Author) & $\begin{array}{l}\text { Subject } \\
\text { Matter }\end{array}$ & Research Question & Methodology & Results & $\begin{array}{c}\text { Lessons for } \\
\text { Sarawak }\end{array}$ \\
\hline $\begin{array}{l}\text { Exploring the } \\
\text { "implementation } \\
\text { gap" in land } \\
\text { registration: How } \\
\text { it happens that } \\
\text { Ghana's official } \\
\text { registry contains } \\
\text { mainly leaseholds } \\
\text { [22] }\end{array}$ & $\begin{array}{c}\text { Land } \\
\text { Administratio } \\
\mathrm{n} \\
\text { (Land } \\
\text { Registration) }\end{array}$ & $\begin{array}{l}\text { How does the gap } \\
\text { between policy and } \\
\text { practice } \\
\text { (implementation } \\
\text { gap) can be } \\
\text { explained? }\end{array}$ & $\begin{array}{c}\text { Case studies; Semi } \\
\text { structured } \\
\text { interviews: } \\
\text { Unstructured } \\
\text { observations; } \\
\text { Comparative } \\
\text { analysis. }\end{array}$ & $\begin{array}{l}\text { A detailed explanation } \\
\text { of the implementation } \\
\text { gap in three groups } \\
\text { namely: legal } \\
\text { simplification versus } \\
\text { real complexities, } \\
\text { administrative } \\
\text { adaptations of the law, } \\
\text { and administrative } \\
\text { capacity. }\end{array}$ & $\begin{array}{l}\text { Identify the factors } \\
\text { which influence } \\
\text { the implementation } \\
\text { such as ambiguity } \\
\text { of the law, } \\
\text { disposition of } \\
\text { implementers to } \\
\text { the aims of the law } \\
\text { and human } \\
\text { resources }\end{array}$ \\
\hline $\begin{array}{l}\text { Land Registration } \\
\text { of Titles at Stake: } \\
\text { West and East } \\
\text { Malaysia } \\
\text { compared [24] }\end{array}$ & $\begin{array}{c}\text { Land } \\
\text { Administratio } \\
\mathrm{n} \\
\text { (Land } \\
\text { Registration) }\end{array}$ & $\begin{array}{c}\text { Is the title } \\
\text { registration system } \\
\text { in Malaysia } \\
\text { susceptible to } \\
\text { fraud? }\end{array}$ & $\begin{array}{l}\text { Documentary } \\
\text { research }\end{array}$ & $\begin{array}{l}\text { Factors caused the } \\
\text { imperfection of title } \\
\text { registration system }\end{array}$ & $\begin{array}{c}\text { Preventive } \\
\text { measures to avoid } \\
\text { fraud }\end{array}$ \\
\hline $\begin{array}{c}\text { The Polish land } \\
\text { administration } \\
\text { system supporting } \\
\text { good governance } \\
\text { [25] }\end{array}$ & $\begin{array}{c}\text { Land } \\
\text { administratio } \\
\mathrm{n} \text { system }\end{array}$ & $\begin{array}{c}\text { Is Polish LAS a } \\
\text { tool to facilitate } \\
\text { public } \\
\text { administration and } \\
\text { contribute to good } \\
\text { governance? }\end{array}$ & $\begin{array}{l}\text { Documentary } \\
\text { research }\end{array}$ & $\begin{array}{l}\text { A correlation between } \\
\text { the functionality of } \\
\text { Poland LAS and the } \\
\text { principles of good } \\
\text { governance }\end{array}$ & $\begin{array}{l}\text { Key factors of } \\
\text { Integrated } \\
\text { database, eg } \\
\text { LASIS in } \\
\text { supporting good } \\
\text { governance }\end{array}$ \\
\hline $\begin{array}{l}\text { Implementing Fit- } \\
\text { For-Purpose land } \\
\text { administration at } \\
\text { Country Level [26] }\end{array}$ & $\begin{array}{c}\text { Land } \\
\text { Administratio } \\
\mathrm{n} \text { System }\end{array}$ & $\begin{array}{l}\text { What are the } \\
\text { strategies to } \\
\text { implement Fit-For- } \\
\text { Purpose (FFP) land } \\
\text { administration in } \\
\text { developing } \\
\text { countries? }\end{array}$ & $\begin{array}{c}\text { Documentary } \\
\text { research; case study }\end{array}$ & $\begin{array}{l}\text { A guide for } \\
\text { implementing FFP as } \\
\text { well as the benefits of } \\
\text { implementing FFP in } \\
\text { the case of India. }\end{array}$ & $\begin{array}{l}\text { FFP solutions to } \\
\text { address the current } \\
\text { issues. }\end{array}$ \\
\hline $\begin{array}{c}\text { Land use and } \\
\text { management in } \\
\text { Benin Republic: } \\
\text { An evaluation of } \\
\text { the effectiveness } \\
\text { of Land Law 2013- } \\
01 \text { [29] }\end{array}$ & $\begin{array}{c}\text { Land } \\
\text { Legislation }\end{array}$ & $\begin{array}{l}\text { What are the effects } \\
\text { of Beninese Land } \\
\text { Law 2013-01 on } \\
\text { land use and land } \\
\text { ownership in } \\
\text { Republic of Benin } \\
\text { since its } \\
\text { implementation? }\end{array}$ & $\begin{array}{l}\text { Documentary } \\
\text { research }\end{array}$ & $\begin{array}{l}\text { An interpretation on } \\
\text { the effectiveness and } \\
\text { limitations of the law }\end{array}$ & $\begin{array}{l}\text { Legal dualism } \\
\text { (coexistence of } \\
\text { customary laws } \\
\text { and the modern } \\
\text { registration } \\
\text { system) may } \\
\text { hinder the } \\
\text { effectives of land } \\
\text { policy }\end{array}$ \\
\hline
\end{tabular}


International Conference on Recents Advancements in Engineering and Technology (ICRAET-18) |15th and 16th March 2019|Siddhartha Institute of Technology \& Sciences, Telangana, India.

Table. 2 (Continue)

\begin{tabular}{llllll}
\hline Title (Author) & $\begin{array}{l}\text { Subject } \\
\text { Matter }\end{array}$ & $\begin{array}{l}\text { Research } \\
\text { Question }\end{array}$ & Methodology & Results & $\begin{array}{l}\text { Lessons for } \\
\text { Sarawak }\end{array}$ \\
\hline $\begin{array}{l}\text { Urban land } \\
\text { readjustment: }\end{array}$ & $\begin{array}{l}\text { Land } \\
\text { readjustmen }\end{array}$ & $\begin{array}{l}\text { What is the } \\
\text { necessity of a }\end{array}$ & $\begin{array}{l}\text { Documentary } \\
\text { research, case }\end{array}$ & $\begin{array}{l}\text { An integrated } \\
\text { analysis of the }\end{array}$ & $\begin{array}{l}\text { Reflection on the } \\
\text { necessity of }\end{array}$ \\
$\begin{array}{l}\text { effective urban } \\
\text { renewal? }\end{array}$ & t; Land & new land policy & studies, & reasons to use ULR & implementing \\
forlation & for urban land & interviews & and the necessity of & new land policy \\
readjustment? & & a ULR legislation. & for ULR
\end{tabular}

Analysing the

Dutch quest for

new legislation

[30]

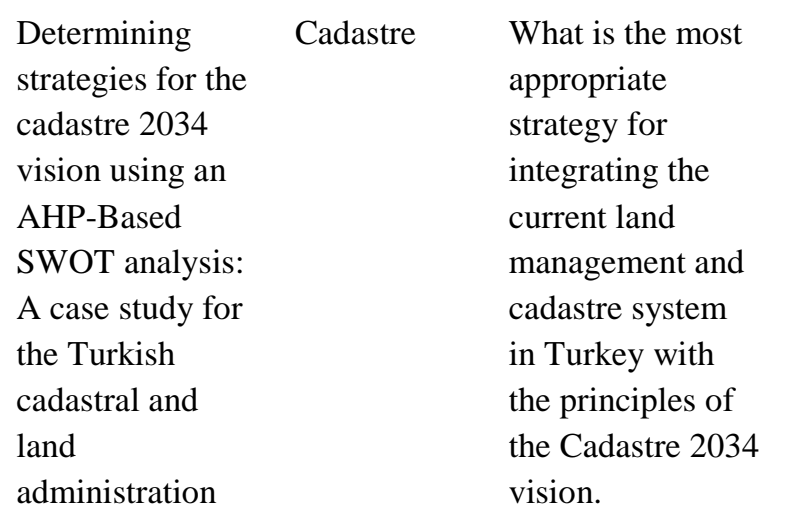

Interviews;

SWOT-AHP

analysis.

system [15]

\begin{tabular}{|c|c|c|}
\hline $\begin{array}{l}\text { Evolving urban } \\
\text { cadastres in } \\
\text { Ethiopia: The } \\
\text { impacts on urban } \\
\text { land governance } \\
\text { [34] }\end{array}$ & Cadastre & $\begin{array}{l}\text { How does the } \\
\text { urban cadastres } \\
\text { support land } \\
\text { governance } \\
\text { across three } \\
\text { governing } \\
\text { regimes in } \\
\text { Ethiopia? }\end{array}$ \\
\hline
\end{tabular}

\author{
Case studies; \\ Questionnaire; \\ interviews; \\ Comparative \\ analysis
}
A framework to analyse the integration of land and cadastre system in Turkey with the principles of the Cadastre 2034 vision by using SWOT-AHP analysis.

$\begin{array}{ll}\begin{array}{ll}\text { A synthesised result } \\ \text { of the role of urban }\end{array} & \begin{array}{l}\text { Key lessons such } \\ \text { as use the } \\ \text { cadastres by using } \\ \text { cadastral } \\ \text { the cadastral }\end{array} \\ \text { 'toolbox' } \\ \begin{array}{l}\text { approach to } \\ \text { examine land } \\ \text { governance }\end{array}\end{array}$

\section{CONCLUSION}

This study reviewed the chronological evolution of land legislation during the pre-Brooke Sarawak, the Brooke era, the British Crown colony and the present Sarawak, Malaysia. The cadastre system in Sarawak is known as the Land and Survey Information System (LASIS) which is managed by a multi-functional organisation which is the Sarawak Land and Survey Department. As compared to Peninsular Malaysia, the land and cadastre system in Sarawak is an integrated and unified system managed by a single department. Under one roof, the activities related to land such as land registration, land dealing, land valuation and land planning can be performed better and faster. A total of eight recent publications were chosen, reviewed and analysed based on the subject matter of land legislation, land administration and cadastre. Based on the analysis, the key lessons for Sarawak are as follows:
- Understanding the nature of implementation gap. Implementation gap is the gap between land policy and performance, causing vague relationship between land policy and real practice.

- Legal dualism may hinder the effectiveness of land policy. Native customary right is a major issue in Sarawak. The coexistence between modern rights and native rights must be clearly defined in the Sarawak Land Code.

- Utilised the cadastre toolbox to examine land governance. This toolbox can be used as an analytical framework to effectively monitor the land governance in Sarawak. 
- The role of LASIS in supporting good governance. Principles of good governance derived from Polish land administration system are openness, participation, accountability, effectiveness and coherence which can be a guideline for the LASIS in Sarawak

- Preventive measures to avoid fraud. In Malaysia, fraud in land title registration can happens whether in paper based or electronic land registration system. As the commonisation of electronic system, the security aspect such as the usage of digital signature must be secured in order to reduce cyber fraud.

- A comprehensive framework to monitor the cadastre system. Analytic hierarchy Process (AHP) together with Strengths, Weaknesses, Opportunities and Threats (SWOT) analysis can be used as a framework to monitor the progress of cadastre in Sarawak in terms of legal, institutional and technical aspects.

- Understanding fit-for-purpose land administration and the benefits. FFP is suitable for developing countries and can be a solution to handle the current issues in Malaysia.

- Understanding urban land readjustment and the need for a new land policy. Currently there isn't any clear policy on land readjustment in Sarawak. However, with the rapid land development happening in Sarawak, there might be a need for a new land policy to implement urban land readjustment.

\section{REFERENCES}

1. Dale PF, McLaughlin JD. Land Information Management. (1st ed.). Clarendon Press, Oxford: Oxford University Press New York; 1988.

2. Dale PF, McLaughlin JD. Land Administration Systems. (1st ed.). Clarendon Press, Oxford: Oxford University Press New York.; 1999.

3. UNECE. Land Administration Guidelines. Meeting of Officials on Land Administration, United Nations Economic Commission of Europe. 1996;ECE/HBP/96.

4. UNECE. Land Administration in The UNECE Region: Development Trends and Main Principles. United Nations Economic Commission for Europe. 2005;ECE/HBP/140.

5. Williamson I, Enemerk S, Wallace J, Rajabifard A. Land Administration for Sustainable Development (1st ed.). California: ESRI Press; 2010.

6. Williamson I. Cadastres and Land Information Systems 1985; Vol. 28(No. 217):114-29.

7. Kaufmann J, Steudler D, editors. Cadastre 2014-A vision for future cadastral system. Working Group 1 of FIG Commission 7; 1998 July 1998.

8. Stoter JE. 3D Cadastre. Delft: Delft Unviersity of Technology; 2004.

9. Oosterom PV, Ploeger H, Stoter J, Thompson R, Lemmen C. Aspects of a 4D Cadastre : A First Exploration. XXIII Fig Congress; Munich, Germany2006.

10. Tan Liat Choon. Towards Developing a ThreeDimensional Cadastre For Three-Dimensional Property Rights In Malaysia: University Technology Malaysia; 2013.

11. Tan LC, Looi KS, editors. Developing Infrastructure Framework to Facilitate the Malaysian Multipurpose 3D Cadastre. FIG Congress 2014; 2014; Kuala Lumpur, Malaysia. in Common Law Jurisdictions. The Survey Review.

12. Zulkifli NA, Rahman AA, JAMIL H, Hua TC, Choon TL, Seng LK, et al., editors. Towards Malaysian LADM Country Profile for 2D and 3D Cadastral Registration System. FIG Congress 2014; 2014; Kuala Lumpur, Malaysia.

13. Jones B, Land N, editors. Cadastre 2.0 - A technology vision for the cadastre of the future. FIG Working Week 2012; 2012; Rome, Italy.

14. Isa MN, Hua TC, Jazuli ARM, Shaharuddin S, Yusof SNM, editors. Cadastral In Supporting Smart Cities In Malaysia. FIG Working Week 2017; 2014; Helsinki, Finland, May 29-June 2, 2017.

15. Polat ZA, Alkan M, Sürmeneli HG. Determining strategies for the cadastre 2034 vision using an AHPBased SWOT analysis: A case study for the turkish cadastral and land administration system. Land Use Policy. 2017;67:151-66.

16. DOSM. Official Website of Department of Statistics Malaysia Department of Statistics Malaysia; 2018

17. Richards AJN. Sarawak Land Law and Adat. 1961.

18. Ngidang D. Deconstruction and Reconstruction of Native Customary Land Tenure in Sarawak. Southeast Asian Studies. 2005;43(1):47-75.

19. Nasser H, Salleh B. Land Law in Sarawak. Subang Indah: Gavel Publications; 2011.

20. Hamzah HF, editor Land Information System for Revenue Planning, Estimates and Collection. FIG Congress 2014; 2014; Kuala Lumpur, Malaysia 16-21 June 2014.

21. Mogalakwe M. The Use of Documentary Research Methods in Social Research. African Sociological Review. 2006;10(1):221-30.

22. Abubakari Z, Richter C, Zevenbergen J. Exploring the "implementation gap" in land registration: How it happens that Ghana's official registry contains mainly leaseholds. Land Use Policy. 2018;78:539-54.

23. Osman S, Kueh HU. Land Administration, Land Management and Spatial Information in Sarawak, Malaysia. FIG International Congress; Sydney: International Federation of Surveyors; 2010. p. 1-16.

24. Nuraisyah CA, Ramly R, Ikhsan MI. Land Registration of Titles at Stake: West and East Malaysia Compared Environment-Behaviour Proceedings Journal 2017;2(6):197-203.

25. Klimach A, Dawidowicz A, Źróbek R. The Polish land administration system supporting good governance. Land Use Policy. 2018;79:547-55.

26. Enemark S, Denmark, Mclaren R, editors. Implementing Fit-For-Purpose Land Administration at Country Level. FIG Working Week 2017; 2017; Helsinki, Finland.

27. UN. Transforming our world: the 2030 agenda for sustainable development. United Nations, New York2015.

28. Schindler G, Schutz E, editors. Fit-for-Purpose Land Administration in Practical Application. FIG Working Week 2017 Surveying the world of tomorrow - From digitalisation to augmented reality; 2017; Helsinki, Finland.

29. Ekpodessi SGN, Nakamura H. Land use and management in Benin Republic: An evaluation of the effectiveness of Land Law 2013-01. Land Use Policy. 2018;78:61-9.

30. Holtslag-Broekhof S. Urban land readjustment: Necessary for effective urban renewal? Analysing the Dutch quest for new legislation. Land Use Policy. 2018;77:821-8 
31. Krabben E, Lenferink S. The introduction of urban land readjustment legislation as an institutional innovation in Dutch land policy. Habitat International. 2018;75:114-21.

32. Ngidang D. Contradictions in land development schemescthe case of joint ventures in Sarawak, Malaysia. Asia Pacific Viewpoint. 2002;43(2):157-80.

33. Enemark S, editor Facing the Global Challenges: the Importance of Land Governance and the Significance of the Cadastre. FIG Commission 7 International Open Symposiums; 2009; 15 October. Kuala Lumpur: InternationalFederation of Surveyors.

34. Alemie BK, Bennett RM, Zevenbergen J. Evolving urban cadastres in Ethiopia: The impacts on urban land governance. Land Use Policy. 2015;42:695-705.

\section{AUTHORS PROFILE}

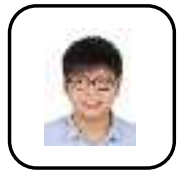

Toh Ming Liang is a $\mathrm{PhD}$ candidate of the Department of Real Estate, Faculty of Built Environment and Surveying, University Technology Malaysia (UTM), Malaysia. His $\mathrm{PhD}$ research focuses on the Land Legislation and Land Administration.

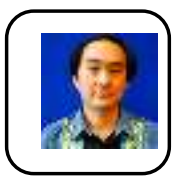

Sr Dr. Tan Liat Choon is a senior lecturer at the Department of Geoinformation, Faculty of Built Environment and Surveying, University Technology Malaysia (UTM), Malaysia. He received his Degree in Land Survey and Master in Land Administration and Development from UTM. In 2013, he received his PhD from UTM for his thesis on "Towards Developing a Three-Dimensional Cadastre for Three-dimensional Property Rights in Malaysia". His research interests focus on 3D property and Land Administration and has successfully published more than 70 research items.

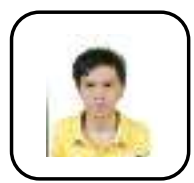

Tan Wee Vern is a $\mathrm{PhD}$ candidate of the Department of Real Estate, Faculty of Built Environment and Surveying, University Technology Malaysia (UTM), Malaysia. His PhD research focuses on the stratified properties in Malaysia

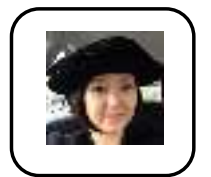

Dr. Thoo Ai Chin is a senior lecturer, internship coordinator, internal auditor and alumni committee of Azman Hashim International Business School (AHIBS). As an internship coordinator for Bachelor of Management (Marketing), she serves as a liaison between AHIBS and business/organizations in the area of marketing. Besides, as an internal auditor, she assists the university in meeting its objectives and improving the effectiveness of risk management, control and governance processes. She is also the alumni committee to strengthen the bond between the institute and alumni for a mutually beneficial relationship.

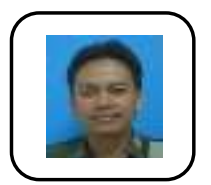

Dr. Muhamad Uznir Bin Ujang is a senior lecture at the Department of Geoinformation, Faculty of Built Environment and Surveying, University Technology Malaysia (UTM). He is a scientific reviewer who performed reviews for journals including ISPRS International Journal of Geo Information and Proceedings of the International Conference on Geomatics \& Geospatial Technology; placing in the 95th percentile for verified review contributions on Publons up until July 2018. With his expertise on 3D geospatial data, he has published more than 50 research items in the related field. 